\title{
The Effect Of Isotonic Drinks On The Body's Recovery Time After Performing The Harvard Step Test
}

\author{
Firman Erdona Sebayang ${ }^{1}$, Refi Ikhtiari ${ }^{2 *}$, Ahmad Raif ${ }^{3}$ \\ 1,2,3 Public Health Department, Faculty Of Medicine Universitas Prima Indonesia Medan, Indonesia \\ *Coresponden Author: \\ Email: refiikhtiari@unprimdn.ac.id
}

\begin{abstract}
.
Sport is an activity that is mostly done in the world. One of the most common problems experienced when exercising is dehydration. Dehydration occurs due to the amount of mineral fluid that is lost / out of the body so that it can cause the body to experience fatigue. During exercise or high physical activity, it has the potential to increase the pulse frequency because the higher the physical activity, the higher the increase in blood flow to supply nutrients and oxygen. The body will experience fatigue as a sign that the body has reached the limit of activity so that the body must rest. When the body rests the body will undergo a recovery process. At the time of recovery, hydration is needed to replace the body's lost minerals. While isotonic drinks have a composition similar to lost body fluids than ordinary mineral water. To determine the effect of isotonic fluid on blood pressure after doing the Harvard Step Test on recovery time, knowing the effect of isotonic fluid on pulse rate after doing the Harvard Step Test on recovery time, knowing the effect of isotonic fluid on Respiration rate after doing the Harvard Step Test on recovery time. The sig-p value of the normality test of recovery time. Respiration rate, heart rate and blood pressure with Shapiro Wilk were 0.001, 0.000 and 0.021 and 0.041, respectively, all of which were smaller than 0.05. The average value of the recovery time for the Respiratory Rate pre-test was 21.93 minutes while the average value for the recovery time for the Respiratory Rate post-test was 9.07 minutes with a sig-p value $=0.000(p<0.05)$. This means that there is a significant decrease in the recovery time of the respiratory rate after administration of isotonic fluids $(p=0.000<0.05)$. The mean (average) recovery time of the pre-test Heart Rate is 21.80 minutes while the average value of the post-test Heart Rate recovery time is 9.20 minutes with a sig$p$ value $=0.000(p<0.05)$. This means that there is a significant decrease in the recovery time of the Heart Rate after administration of isotonic fluids $(p=0.000<0.05)$. The average value of recovery time for pre-test blood pressure was 21.20 minutes while the average value of recovery time for post-test blood pressure was 9.80 minutes with sig- $p=0.000(p<0.05)$. This means that there is a significant decrease in blood pressure recovery time after administration of isotonic fluids $(p=0.000<0.05)$. The average value of the recovery time for the respiratory rate pre-test was 21.03 minutes while the average value for recovery time for the respiratory rate posttest was 9.97 minutes with a sig-p value $=0.000(p<0.05)$. This means that there is a significant decrease in the recovery time of the Respiration Rate after giving mineral water $(p=0.000<0.05)$. The average pre-test heart rate recovery time was 21.70 minutes while the post-test heart rate recovery time average was 10.30 minutes with sig- $p=0.000(p<0.05)$. This means that there is a significant decrease in the recovery time of the Heart rate after giving mineral water $(p=0.000<0.05)$. The average value of recovery time for pre-test blood pressure was 16.27 minutes while the average value of post-test BP recovery time was 14.73 minutes with sig- $p$ value $=0.653$ $(p>0.05)$. This means that there is no significant decrease in blood pressure recovery time after administration of mineral water $(p=0.000<0.05)$. The average value of isotonic recovery time is 36.68 minutes while the average value of mineral water recovery time is 54.32 minutes with a sig-p value $=0.001(p<0.05)$.
\end{abstract}

Keywords: Exercise, Body Fluids, Harvard Step Test.

\section{INTRODUCTION}

Exercise is an activity that is widely done in the world and one of the most common problems experienced when exercising is dehydration. Dehydration occurs due to the amount of mineral fluid that is lost / out of the body, so that it can cause the body to experience fatigue. At the time of exercise or high physical activity has the potential to increase the frequency of the pulse, because the higher the physical activity, the higher the increase in blood flow to supply nutrients and oxygen. The body will experience fatigue as a sign that the body has reached the limit of activity so that the body must rest. When the body rests the body will undergo a recovery process. At the time of recovery, hydration is needed to replace the body's lost minerals. While isotonic drinks have a composition similar to lost body fluids than ordinary mineral water (Kurniawan, 2014).Physical activity causes changes in the physiological parameters of the human body such as oxygen consumption, heart rate, body temperature and changes in chemical compounds in the body (Irawan 2007). Sweat lost during activity varies between $0.4-2.6$ liters per hour depending on the individual and the type of activity. As a result, the body loses minerals such as sodium, potassium, 
magnesium, iron and zinc. Sodium functions to regulate blood $\mathrm{pH}$, fluid balance and osmotic pressure so that cell shrinkage does not occur due to pressure differences

\section{METHOD}

Rancangan penelitian yang digunakan adalah penelitian Eksperimental Pretest - Posttest Control Group Design (Pocock, 2008).

Treatment 1

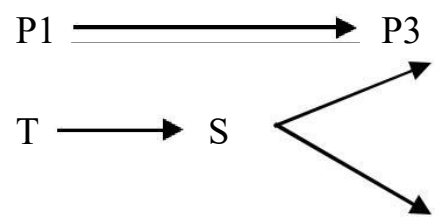

Treatment 2

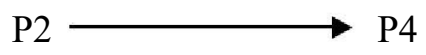

Fig. 3.1. Research Design

Information:

$\mathrm{T}$ : Population

$\mathrm{S}$ : Sample

P1 : Observation of group 1, recovery time after doing the Harvard Step Test activity.

P2 : Observation of group 2, recovery time after doing the Harvard Step Test activity.

P3 : Observation of group 1, recovery time after carrying out the Harvard Step Test activity given treatment 1.

P4 : Observation of group 2, recovery time after carrying out the Harvard Step Test activity given treatment 2.

The research was conducted from January 2019 to February 2019 at SMA Negeri 1 Kuala.

The research population was all students of SMA Negeri 1 Kuala Langkat Regency.

The sampling technique is all students who meet the following inclusion criteria:

a) Aged 17-18 years old,

b) Body mass index: normal 918.5-24.9,

c) In good health and not physically disabled,

d) Willing to participate in research by signing informed consent.

\section{RESULTS AND DISCUSSION}

Table 1. Hypothesis Test Results 1 Effect of Isotonic Fluid on Recovery Time Respiration Rate

\begin{tabular}{|l|c|c|c|}
\hline \multicolumn{1}{|c|}{ Parameter } & Rata-Rata & Z & p-value \\
\cline { 1 - 2 } Respirasi Rate Pretest & 21.93 & \multirow{2}{*}{-4.215} & 0.000 \\
\cline { 1 - 3 } Respirasi Rate Postest & 9.07 & & \\
\hline
\end{tabular}

Table 1 shows that the average recovery time for the respiratory rate pre-test is 21.93 minutes while the average value for recovery time for the post-test respiratory rate is 9.07 minutes with a sig-p value $=0.000$ $(p<0.05)$. there was a significant decrease in the recovery time of the respiratory rate after the administration of isotonic fluids $(p=0.000<0.05)$ so it can be concluded that the use of isotonic fluids had a significant effect on the recovery time of the respiratory rate. Thus, the use of isotonic fluids has been successful in accelerating the recovery time of the Respiratory Rate.

Table 2. Hypothesis Test Results 1 Effect of Isotonic Fluid on Heart Rate Recovery Time

\begin{tabular}{|l|c|c|c|}
\hline Parameter & Rata-Rata & Z & P-Value \\
\hline Heart Rate Pretest & 21.80 & -4.201 & 0.000 \\
\hline Heart Rate Postest & 9.20 & -400 & \\
\hline
\end{tabular}


Table 2, shows that the average (average) recovery time of the pre-test Heart Rate is 21.80 minutes while the average value of the post-test Heart Rate recovery time is 9.20 minutes with a sig-p value of $0.000(p<0.05)$. There was a significant decrease in Heart Rate recovery time after the use of isotonic fluids $(p=0.000<0.05$ ) so it can be concluded that the use of isotonic fluids had a significant effect on Heart Rate recovery time. Thus, administration of isotonic fluids has succeeded in accelerating the recovery time of the Heart Rate.

Table 3. Hypothesis Test Results 1 Effect of Isotonic Fluid on Blood Pressure Recovery Time

\begin{tabular}{|c|c|c|c|}
\hline Parameter & Rata-Rata & Z & p-value \\
\cline { 1 - 2 } Tekanan Darah Pretest & 21.20 & -3.657 & 0.000 \\
\hline Tekanan Darah Postest & 9.80 & & \\
\hline
\end{tabular}

Table 3, shows that the average value of recovery time for pre-test blood pressure is 21.20 minutes while the average value of recovery time for post-test blood pressure is 9.80 minutes with sig- $p=0.000(p<0.05)$. There was a significant decrease in blood pressure recovery time after the use of isotonic fluids $(\mathrm{p}=0.000$ $<0.05$ ) so it can be concluded that the use of isotonic fluids had a significant effect on blood pressure recovery time. Thus, the use of isotonic fluids has been successful in accelerating the recovery time of blood pressure.

Table 4. Hypothesis Test Results 1 Effect of Mineral Water on Recovery Time Respiration Rate

\begin{tabular}{|l|c|c|c|}
\hline \multicolumn{1}{|c|}{ Parameter } & Rata rata & Z & p-value \\
\cline { 1 - 2 } Respirasi Rate Pretest & 21.03 & \multirow{2}{*}{-3.963} & 0.000 \\
\cline { 1 - 2 } Respirasi Rate Postest & 9.97 & & \\
\hline
\end{tabular}

Table 4, shows that the average recovery time for the respiratory rate pre-test is 21.03 minutes while the average value for recovery time for the respiratory rate post-test is 9.97 minutes with a sig-p value $=0.000$ $(p<0.05)$. This means that there is a significant decrease in the recovery time of the Respiration Rate after the use of mineral water $(p=0.000<0.05)$. It was concluded that the use of mineral water had a significant effect on the recovery time of the Respiration Rate. Thus, the use of mineral water has succeeded in accelerating the recovery time of the Respiration Rate.

Table 5. Hypothesis Test Results 1 Effect of Mineral Water on Recovery Time Respiration Rate

\begin{tabular}{|c|c|c|c|}
\hline Parameter & Rata-Rata & $\mathbf{Z}$ & p-value \\
\hline Heart Rate Pretest & 21.70 & \multirow{2}{*}{-3.593} & 0.000 \\
\hline Heart Rate Postest & 10.30 & & \\
\hline
\end{tabular}

Table 5, Shows that the average recovery time for the pre-test heart rate is 21.70 minutes while the average recovery time for the post-test heart rate is 10.30 minutes with a sig-p value of $0.000(p<0.05)$. There was a significant decrease in Heart Rate recovery time after using mineral water $(p=0.000<0.05)$, so it was concluded that the use of mineral water had a significant effect on Heart Rate recovery time. Thus, the use of mineral water has succeeded in speeding up the recovery time of the Heart Rate.

Table 6. Hypothesis Test Results 1 Effect of Mineral Water on Blood Pressure Recovery Time

\begin{tabular}{|c|c|c|c|}
\hline \multicolumn{1}{|c|}{ Parameter } & Rata-Rata & $\mathbf{Z}$ & p-value \\
\cline { 1 - 2 } Tekanan Darah Pretest & 16.27 & \multirow{2}{*}{-0.571} & \multirow{2}{*}{0.653} \\
\hline Tekanan Darah Postest & 14.73 & \\
\hline
\end{tabular}

Table 6: Shows that the average pre-test BP recovery time is 16.27 minutes while the Post-Test BP recovery average value is 14.73 minutes with a sig-p value of $0.653(\mathrm{p}>0.05)$. There was no significant decrease in blood pressure recovery time after the use of mineral water $(p=0.000<0.05)$ so it was concluded that the use of mineral water had no significant effect on blood pressure time. So, the use of mineral fluids does not succeed in speeding up the recovery time of Blood Pressure.

Table 7. Differences in Effect of Isotonic Fluid and Mineral Water on Recovery Time on Respiration Rate, Heart Rate and Blood Pressure

\begin{tabular}{|l|c|c|c|}
\hline \multicolumn{1}{|c|}{ Waktu Pemulihan } & Rata-Rata & Z & p-value \\
\cline { 1 - 2 } Isotonik & 36.68 & \multirow{2}{*}{-3.291} & 0.001 \\
\hline Mineral & 54.32 & -29 & \\
\hline
\end{tabular}


Table 7: Shows that the average value of isotonic recovery time is 36.68 minutes while the average value of mineral water recovery time is 54.32 minutes with a sig-p value $=0.001(\mathrm{p}<0.05)$. This means that there is a significant difference in the effect of isotonic fluids with mineral water on the recovery time of Respiration Rate, Heart Rate and Blood Pressure, indicating that the recovery time produced by isotonic fluids is much shorter than the recovery time produced by mineral water.

\section{CONCLUSION}

Based on the results of research and data analysis on the effect of isotonic fluids and mineral water on the recovery time of Respiration Rate, Heart Rate and Blood Pressure in students of SMA Negeri 1 Kuala Langkat Regency, it can be concluded that:

1. The use of isotonic fluid has a significant effect on recovery time. Respiration rate $(0=0.000<0.05)$. In other words, the use of isotonic water has succeeded in accelerating the recovery time of the respiratory rate.

2. The use of isotonic fluid has a significant effect on the recovery time of the Heart Rate $(0=0.000<$ 0.05). Thus, the use of isotonic water has succeeded in accelerating the recovery time of the Heart Rate.

3. The use of isotonic fluid has a significant effect on the recovery time of blood pressure $(0=0.000<$ 0.05). Thus, the use of isotonic water has succeeded in accelerating the recovery time of blood pressure.

4. The use of mineral water has a significant effect on the recovery time of the Respiration Rate $(0=$ $0.000<0.05)$. Thus, the use of mineral water has succeeded in accelerating the recovery time of the Respiration Rate.

5. The use of mineral water has a significant effect on the recovery time of the Heart rate $(0=0.000<0.05)$. So, the use of mineral water has succeeded in speeding up the recovery time of the Heart Rate.

6. The use of mineral water did not significantly affect the recovery time of blood pressure $(0=0.653>0.05)$. So, the use of mineral water does not succeed in accelerating the recovery time of blood pressure.

7. There is a significant difference between isotonic fluid and mineral water on the recovery time of Respiration Rate, Heart Rate and Blood Pressure, where isotonic fluid is much more effective in reducing the recovery time of Respiration Rate, Heart Rate and Blood Pressure.

\section{Special Thanks}

I am very grateful to all those who have helped in providing input or advice and guidance in completing this research.

\section{REFERENCES}

[1] Anonim. 2011. Minuman Olah Raga, Isotonik dan Energi.

Available at: http://finance.dir.groups.yahoo.com/group/Foodtech-Indonesia/ message/ 564.

[2] Anonim. 2011. Modul Biomekanika. Laboratorium APK I Ergonomi. Universitas Islam Indonesia.

[3] Boron, W.F., Boulpaep,E.L. 2008.Medical Physiology A Cellular and Molecular Approach. SecondEdition.Ohio:SaundersElsevier. Hal: 1237- 1242, 1261, 1262.

[4] Ganong, W.F.2008. Fisiologi Kedokteran. Editor H.M. Djauhari Wijayakusumah. Edisi 20. Jakarta: Penerbit Buku Kedokteran EGC..

[5] Guyton, A.C., Hall J.E. 2007. Buku Ajar Fisiologi Kedokteran. alih bahasa Irawati. Ed. 11. Jakarta: EGC. Hal: 379

[6] Hamidin,A.S.2010.Kebaikan Air Putih. Penyunting: Retino.Cetakan1. Yogyakarta: Media Pressindo. Hal: 29.

[7] Hartanto, W.W. 2007. Terapi Cairan dan Elektrolit Perioperatif. Bagian Farmakologi Klinik dan Terapeutik Fakultas Kedokteran Universitas Padjajaran. Laporan Penelitian.

[8] Irawan, M.A. 2007. Cairan Tubuh, Elektrolit dan Mineral. Polton Sport Science Brief \& Lab. Volume 01. No.1. Available from: http://www.pssplab.com / journal/01.pdf.

[9] Kuntarti. 2011. Keseimbangan Cairan, Elektrolit, Asam dan Basa. Avaiable from: http://proemergencylibrary.blogspot.com/2009/08/keseimbangan - cairan-elektrolit-asam-dan.html.

[10] Levy, M.N. Stanton, B.A. Koeppen, B.M. 2008. Berne And Levy Principles of Physiology. $4^{\text {th }}$ ed. Editors 
Matthew N. Levy, Bruce M. Koeppen, Bruce A. Stanton. Philadelphia: Mosby Inc. hal: 260, 332, 480 - 483, 533.

[11] Maughan dan Murray. 2011. Minuman Olah Raga, Isotonik dan Energi.

Available from: http://finance.dir.groups.yahoo.com/group/Foodtech-Indonesia/message/564 .

[12] Mutohir, T.C. Maksum, A. 2007. Sport Development Index: Konsep, Metodelogi dan Aplikasi. Jakarta: PT Indeks. Hal: 57.

[13] Nur. B.M. 2011. Cairan Tubuh. Avaiable from:

http://repository.ui.ac.id/ contents/ koleksi/11/7facbe0010ae548cae100e83cf57da86fd7f5f03.pdf [23 Pebruari 2011].

[14] Plowman. Sharon, A. Smith, D.L. 2008. Exercise Physiology for Health, Fittness, and Performance. $2^{\text {nd }}$ ed. Baltimore: Lippincott Williams \& Wilkins, a Wolters Kluwer Bisiness. Hal: 6.

[15] Pocock, S.J. 2008. Clinical Trials, John Wiley \& Sons Ltd, England.

[16] Respati, S. 2008. Peran Ganda Beserta Tingkat Kelelahan Dosen Wanita di Daerah Istimewa Yogyakarta. Laporan Penelian.

[17] Sherwood, L. 2013. Fisiologi Manusia Dari Sel Ke Sistem. Alih bahasa Brahm U. Pendit. Editor Beatrica I. Santoso. Ed. 2. Jakarta: EGC. hal: 340.

[18] Suraatmaja, S. 2015. Kapita Selekta Gastroenterologi Anak. Jakarta: Sagung Seto. Hal: 44-49, 53-57.

[19] Susanto. 2008. Mekanisme Kerja Minuman Isotonik di Dalam Tubuh. Avaiable from: http://susantopharmacia.blogspot.com/2008/03/isotonic-drink-do-we-really-need-it.html

[20] Susilowati. 2008. Pengukuran Status Gizi dengan Antrometri.

Avaiable from:http://www.eurekaindonesia.org/wp-content/upload/antrometri_gizi.pdf.

[21] Syaifuddin. 2012. Fungsi Sistem Tubuh Manusia Editor: Monica Ester. Jakarta: Widya Medika. Hal: 146.

[22] Tortora, G.J., Derrickson, B.. 2009. Principles of Anatomy and Phisiology: Organization, Support and Movement, and Control of The Human Body. $12^{\text {th }}$ edition. Volume 1. Asia: John Wiley \& Sons, Pte Ltd. Hal: 301-302.

[23] Tortora, G.J., Derrickson, B.. 2009. Principles of Anatomy and Phisiology: Maintenance and Continuity of The Human Body. $12^{\text {th }}$ edition. Volume 2. Asia: John Wiley \& Sons, Pte Ltd. 